\title{
Efficacy of Beauveria Bassiana and Abamectin in the control of strawberry mite - Phytonemus pallidus (Banks) (Acari: Tarsonemidae) and the susceptibility of cultivars to pest infestation
}

\author{
Barbara H. Łabanowska*, Małgorzata Tartanus, Małgorzata Gruchała and Agnieszka Masny \\ Research Institute of Horticulture, Skierniewice, Poland
}

\begin{abstract}
.
BACKGROUND: The Strawberry is an economically important crop in Poland. However, the production of strawberries is difficult and costly, as pests and pathogens causing diseases often damage plants. The strawberry mite - Phytonemus pallidus (Banks) is the most dangerous among pests and one of the most difficult to control. In the past, active substances such as Endosulfan, Amitraz and Propargite, were used to control the pest but they have been withdrawn from the pest control program a few years ago.

OBJECTIVE: The intention of this study was to evaluate the efficacy of Abamectin and fungus Beauveria bassiana to control the strawberry mite on strawberry plants in the open field, as well as the susceptibility of selected strawberry varieties and genotypes to the pest.

METHODS CONTROL EXPERIMENTS: Studies were performed on 'Honeoye' plants. Naturalis (Beauveria basiana) at a dose of $1.0-1.5$ 1/ha+adjuvant Protector (pine resins) at a dose of $0.31 /$ ha, Naturalis -1.0 l/ha+TerraSorb ${ }^{\circledR}$ Complex SB ( $\alpha-$ amino acids, biostimulants) - 1.5 1/ha (2013) and Vertimec $018 \mathrm{EC}$ (abamectin) at a dose of $1.0 \mathrm{l} / \mathrm{ha}$ were estimated. The population of strawberry mite was notated both before, and after the application of the tested products.

SUSCEPTIBILITY OF CULTIVARS: The observations of the strawberry mite presence on the strawberry cultivars, were carried out in years 2012-2013 on an experimental cultivar trial plantation. The population of the pest was counted on strawberry leaves, taken from plants of different varieties and genotypes.

RESULTS: Vertimec 018 EC showed good efficacy in the control of the strawberry mite, but the long-lasting effect was observed only following two applications of the product. Naturalis (Beauveria bassiana)+Protector proved to be more effective than the treatment of Naturalis+TerraSorb ${ }^{\circledR}$ Complex, however the pest control was poorer and of short duration than after application of Vertimec 018 EC.

CONCLUSIONS: In experiments carried out in the open field Abamectin proved to be more effective than Naturalis.

Some strawberry varieties such as 'Dukat', 'Flair', 'Real', 'Salut', 'Vima Rina', 'Malling Pearl' were not infested by to strawberry mite - the pest specimens were not observed on experimental plots within two years of this experiment.

A high population of the strawberry mite was noted on strawberry cultivars such as 'Evita', 'Hokent', 'Albion', 'Feriusz', 'Honeoye' and 'Karel'.
\end{abstract}

Keywords: Strawberry, strawberry mite, Phytonemus pallidus, chemical control, biological control, abamectin, Vertimec 018 EC, Naturalis - Beauveria bassiana, varieties susceptibility

\footnotetext{
*Corresponding author: Barbara H. Łabanowska, Research Institute of Horticulture, Skierniewice, Poland. E-mail: Barbara.Labanowska @inhort.pl.
} 


\section{Introduction}

The strawberry mite (Phytonemus pallidus) was noted in Poland for the first time about eighty years ago [1]. Since then it is considered to be the most dangerous pest of strawberry plants in many countries [2-5, 14-17]. The mites cause damage to the youngest leaves as well as to flower buds, flowers and fruits. The pest is noted not only on fruiting plantations, but also on mother plantations and runners. Most strawberry cultivars are susceptible to colonization by P. pallidus [5,6]. The peak of mite population is observed in the summer: July and August, but mite specimens are noted on plantations from May until August, while the pest develops 4-5 generations in a season. The pest control strategy is very difficult, because it is feeding on the youngest, still curled and unopened leaves. Due to the high degree of infestation in Poland, there is a persistent need to control the pest. The main active substances of insecticides such as Endosulfan, Amitraz and Propargite, previously used to control mites were withdrawn a few years ago [7]. Therefore, the aim of many researchers is to find and evaluate new possibilities to control strawberry mite [7-18].

The intention of this study was to evaluate the efficacy of Abamectin as Vertimec 018 EC (not registered to use on strawberry plantations in Poland) and fungus Beauveria bassiana as Naturalis to control the strawberry mite on strawberry plants in the open field. Additionally, the susceptibility of some strawberry cultivars to the strawberry mite, was estimated in the field on an experimental trial plantation.

\section{Material and methods}

The experiments were carried out at the Research Institute of Horticulture in Skierniewice, central Poland, in the years 2012-2013.

\subsection{Control experiments}

The efficacy of Naturalis (Beauveria bassiana)+Protector and Naturalis+TerraSorb ${ }^{\circledR}$ Complex as well as Vertimec $018 \mathrm{EC}$ were estimated (Table 1). The population of strawberry mite was estimated both before and after the application of tested products. Results are shown in Tables $2-5$.

In 2012 the experiment was carried out on a 2-year-old strawberry plantation of 'Honeoye' cv. and the treatments were applied after fruit harvest. In combination with one treatment, Vertimec $018 \mathrm{EC}(1.0 \mathrm{l} / \mathrm{ha})$ was applied on 16 th July, and in combinations with two treatments, Vertimec $18 \mathrm{EC}(0.75 \mathrm{l} / \mathrm{ha})$ and Naturalis ( 1.0 1/ha) + Protector $(0.3$ 1/ha) were applied on the 16th and 23rd of July. The next experiment was carried out also on 'Honeoye' cv., in the spring of 2013 (treatment on the 15th of May). The experiments were established in a random block design, in four replications; plot size of $50 \mathrm{~m}^{2}(2,5 \mathrm{~m} \times 20 \mathrm{~m})$. Treatments were applied using a knapsack motor sprayer "Stihl", tank capacity of 14 liters, using 5001 of spraying liquid per ha.

The strawberry mites population density, was estimated just before treatment and three times after spraying, with one to two week intervals. The motile forms (adults and larvae) of mites and eggs were counted separately on the youngest, small, still curled leaves, under a stereoscopic microscope. The samples of 10 leaves were taken randomly from each plot/replication, on each counting date.

The results were analyzed statistically using an analysis of variance, performed on the values transformed by logarithmic transformation $\mathrm{y}=\log (\mathrm{x}+1)$, where $\mathrm{x}$ - number of motile stages or eggs per 10 leaves. The significance

Table 1

Characteristic of products employed in experiments

\begin{tabular}{lccc}
\hline Commercial name & Rate 1/ha & Ingredient & Name factories \\
\hline Naturalis & $1.0-1.5$ & Beauveria bassiana & Intrachem Bio, Italia \\
Protector Adjuvant & 0.3 & Pine resins & Miller Chemical $\odot$ Fertilizer Crop Germany \\
Vertimec 018 EC & $0.75-1.0$ & Abamectin & Syngenta Crop Protection \\
Terra Sorb ${ }^{\circledR}$ Complex Biostimulants & 1.5 & $\alpha$-amino acids & Bioiberica, Spain \\
\hline
\end{tabular}


Table 2

Efficacy of the strawberry mite (Phytonemus pallidus) control on strawberry expressed as number of motile forms and eggs. Jamno 2012

\begin{tabular}{|c|c|c|c|c|c|c|}
\hline \multirow[t]{2}{*}{ Treatment } & \multirow[t]{2}{*}{ Rate in $1 /$ ha } & \multirow[t]{2}{*}{ Number of sprays } & \multicolumn{4}{|c|}{ No of motile forms and eggs per 1 leaf } \\
\hline & & & $\begin{array}{l}1 \text { week after } 1 \mathrm{st} \\
\text { treatment } 23.07\end{array}$ & $\begin{array}{l}1 \text { week after } 2 \mathrm{nd} \\
\text { treatment } 30.07\end{array}$ & $\begin{array}{c}3 \text { weeks after } 2 \text { nd } \\
\text { treatment } 13.08\end{array}$ & $\begin{array}{c}5 \text { weeks after } 2 \text { nd } \\
\text { treatment } 28.08\end{array}$ \\
\hline \multicolumn{7}{|l|}{ Motile forms } \\
\hline 1. Check - untreated & & & $11.2 b^{*}$ & $8.0 \mathrm{~b}$ & $7.4 \mathrm{~b}$ & $7.4 \mathrm{~b}$ \\
\hline 2. Naturalis + Protector & $1.0+0.3$ & 2 & $3.4 \mathrm{~b}$ & $1.6 \mathrm{a}$ & $2.5 \mathrm{~b}$ & $3.6 \mathrm{bc}$ \\
\hline 3. Vertimec $018 \mathrm{EC}$ & 0.75 & 2 & $0.8 \mathrm{a}$ & $0.5 \mathrm{a}$ & $2.3 \mathrm{~b}$ & $0.1 \mathrm{a}$ \\
\hline 4. Vertimec $018 \mathrm{EC}$ & 1 & 1 & $1.2 \mathrm{a}$ & $1.2 \mathrm{a}$ & $0.5 \mathrm{a}$ & $2.7 \mathrm{~b}$ \\
\hline \multicolumn{7}{|l|}{ Eggs } \\
\hline 1. Check - untreated & & & $5.2 \mathrm{~b}$ & $7.8 \mathrm{~b}$ & $7.0 \mathrm{~b}$ & $14.6 \mathrm{c}$ \\
\hline 2. Naturalis+Protector & $1.0+0.3$ & 2 & $4.6 \mathrm{~b}$ & $1.8 \mathrm{a}$ & $5.6 \mathrm{~b}$ & $4.3 \mathrm{~b}$ \\
\hline 3. Vertimec 018 EC & 0.75 & 2 & $0.7 \mathrm{a}$ & $0.4 \mathrm{a}$ & $2.0 \mathrm{ab}$ & $0.1 \mathrm{a}$ \\
\hline 4. Vertimec $018 \mathrm{EC}$ & 1 & 1 & $1.2 \mathrm{a}$ & $0.9 \mathrm{a}$ & $0.4 \mathrm{a}$ & $3.3 \mathrm{~b}$ \\
\hline
\end{tabular}

*Means fallowed by the same letter in each column are not significantly different (Student-Newman-Keuls 'test, $p=0,05$ ) Treatments on: 16 th July, 2012 and 23th July, 2012. Before treatments was observed $4.2-7.9$ motile forms and $6.2-10.8$ eggs per 1 leaf.

Table 3

The effectiveness (in\%) of control of strawberry mite (Phytonemus pallidus) on strawberry calculated according Abbott's formula (motile forms and eggs), Jamno 2012

\begin{tabular}{|c|c|c|c|c|c|c|}
\hline \multirow[t]{2}{*}{ Treatment* } & \multirow[t]{2}{*}{ Rate in $1 /$ ha } & \multirow[t]{2}{*}{ Number of sprays } & \multicolumn{4}{|c|}{ Efficacy [\%] } \\
\hline & & & $\begin{array}{l}1 \text { week after } 1 \mathrm{st} \\
\text { treatment } 23.07\end{array}$ & $\begin{array}{l}1 \text { week after } 2 \text { nd } \\
\text { treatment } 30.07\end{array}$ & $\begin{array}{c}3 \text { weeks after } 2 \text { nd } \\
\text { treatment } 13.08\end{array}$ & $\begin{array}{c}5 \text { weeks after } 2 \text { nd } \\
\text { treatment } 28.08\end{array}$ \\
\hline \multicolumn{7}{|l|}{ Motile forms } \\
\hline 2. Naturalis+Protector & $1.0+0.3$ & 2 & 69.5 & 80.2 & 66.4 & 51.3 \\
\hline 3. Vertimec $018 \mathrm{EC}$ & 0.75 & 2 & 93 & 93.4 & 69.1 & 98.7 \\
\hline 4. Vertimec $018 \mathrm{EC}$ & 1 & 1 & 89.5 & 85 & 93.6 & 63.3 \\
\hline \multicolumn{7}{|l|}{ Eggs } \\
\hline 2. Naturalis+Protector & $1.0+0.3$ & 2 & 11.6 & 77.3 & 20.8 & 70.5 \\
\hline 3. Vertimec $018 \mathrm{EC}$ & 0.75 & 2 & 86.5 & 94.2 & 70.9 & 99.1 \\
\hline 4. Vertimec $018 \mathrm{EC}$ & 1 & 1 & 77.2 & 87.5 & 94.6 & 77.4 \\
\hline
\end{tabular}

*Explanation: see Table 2.

of differences between means, was assessed using Student-Newman-Keuls test at a significance level of $P=0.05 \%$. On the basis of the actual values, pest mortality was calculated according to Abbott's formula (1925), which has the form: $\mathrm{C}=\mathrm{A}-\mathrm{B} / \mathrm{Ax} 100 \%$ where: $\mathrm{C}$ - \% of effective, $\mathrm{A}$ - number of motile forms or eggs on the control plot, and B the number of motile forms or eggs on treated plot. The date and number of the treatments and dosage of the product, as well as results are shown in Tables 2-5.

\subsection{Susceptibility of cultivars}

The experiments were carried out in 2012-2013 on strawberry plants growing in the cultivar trial collection belonging to the Department of Fruit Plant Breeding in Pomology Orchard in Skierniewice. The aim of the experiment was the evaluation of the susceptibility of selected strawberry cultivars and genotypes plants to colonization by strawberry mite. In order to estimate the number of strawberry mite the observations were carried out on 7th July 2012 and 19th June 2013. From plants of each variety 20 youngest, still curled leaves were collected and the number of 
Table 4

Efficacy of the strawberry mite (Phytonemus pallidus) control on strawberry expressed as number of motile forms and eggs. Bobrowa 2013

\begin{tabular}{|c|c|c|c|c|}
\hline \multirow[t]{3}{*}{ Treatment } & \multirow[t]{3}{*}{ Rate in $1 / \mathrm{ha}$} & \multicolumn{3}{|c|}{$\begin{array}{c}\text { No of motile forms and } \\
\text { eggs per } 1 \text { leaf } \\
\text { weeks after treatment }\end{array}$} \\
\hline & & 1 & 3 & 5 \\
\hline & & 22.05 & 5.06 & 19.05 \\
\hline 1. Check - untreated & & $0.9 \mathrm{~b}^{*}$ & $4.9 \mathrm{~b}$ & $2.8 \mathrm{a}$ \\
\hline 2. Naturalis+Protector & $1.0+0.3$ & $0.1 \mathrm{a}$ & $0.6 \mathrm{ab}$ & $2.5 \mathrm{a}$ \\
\hline 3. Naturalis+Protector & $1.5+0.3$ & $0.6 \mathrm{ab}$ & $0.7 \mathrm{ab}$ & $2.7 \mathrm{a}$ \\
\hline 4. Naturalis+TerraSorb & $1.0+1.5$ & $0.4 \mathrm{ab}$ & $1.0 \mathrm{ab}$ & $1.4 \mathrm{a}$ \\
\hline 5. Vertimec $018 \mathrm{EC}$ & 1 & $0.0 \mathrm{a}$ & $0.1 \mathrm{a}$ & $0.5 \mathrm{a}$ \\
\hline 1. Check - untreated & & $0.2 \mathrm{ab}$ & $8.0 \mathrm{~b}$ & $7.7 \mathrm{a}$ \\
\hline 2. Naturalis+Protector & $1.0+0.3$ & $0.0 \mathrm{a}$ & $1.1 \mathrm{ab}$ & $5.0 \mathrm{a}$ \\
\hline 3. Naturalis+Protector & $1.5+0.3$ & $0.1 \mathrm{ab}$ & $1.4 \mathrm{ab}$ & $2.9 \mathrm{a}$ \\
\hline 4. Naturalis+TerraSorb & $1.0+1.5$ & $0.8 \mathrm{~b}$ & $1.3 \mathrm{ab}$ & $3.6 \mathrm{a}$ \\
\hline 5. Vertimec $018 \mathrm{EC}$ & 1 & $0.0 \mathrm{a}$ & $0.1 \mathrm{a}$ & $0.4 \mathrm{a}$ \\
\hline
\end{tabular}

* Means fallowed by the same letter in each column are not significantly different (Newman-Keuls 'test, $p=0,05)$ One treatment on: 15 th May, 2013. Before treatments was observed $0.3-1.5$ motile forms and $0.1-0.3$ eggs per 1 leaf.

Table 5

The effectiveness (in\%) of control of strawberry mite (Phytonemus pallidus) on strawberry calculated according Abbott' s formula (motile forms and eggs), Bobrowa 2013

\begin{tabular}{|c|c|c|c|c|}
\hline \multirow[t]{3}{*}{ Treatment* } & \multirow[t]{3}{*}{ Rate in $1 /$ ha } & \multicolumn{3}{|c|}{$\begin{array}{c}\text { Efficacy [\%] } \\
\text { weeks after treatment }\end{array}$} \\
\hline & & 1 & 3 & 5 \\
\hline & & 22.05 & 5.06 & 19.05 \\
\hline 2. Naturalis + Protector & $1.0+0.3$ & 91 & 87 & 12 \\
\hline 3. Naturalis + Protector & $1.5+0.3$ & 34 & 85 & 5 \\
\hline 4. Naturalis + TerraSorb & $1.0+1.5$ & 54 & 79 & 51 \\
\hline 5. Vertimec $018 \mathrm{EC}$ & 1 & 97 & 98 & 82 \\
\hline 2. Naturalis + Protector & $1.0+0.3$ & 100 & 87 & 34 \\
\hline 3. Naturalis + Protector & $1.5+0.3$ & 43 & 82 & 63 \\
\hline 4. Naturalis + TerraSorb & $1.0+1.5$ & 0 & 83 & 53 \\
\hline 5. Vertimec $018 \mathrm{EC}$ & 1 & 100 & 98 & 94 \\
\hline
\end{tabular}

*Explanation: see Table 4.

motile forms (adults and larvae) and eggs present on both sides of leaves were assessed under binocular microscope. In 2013 the plants were very weak after severe winter, many of them were damaged by adverse weather conditions (dried out). The results are given in Tables 6 and 7.

\section{Results and discussion}

\subsection{Control experiments}

In the field experiment in 2012 (Tables 2 and 3) product Naturalis (1.0 1/ha)+Protector (0.3 1/ha) applied twice after fruit harvest showed high efficacy at the level $80.2 \%$ of the motile forms and $77.3 \%$ of the eggs control at one week after the second treatment. Later an increase of pest population was noted. 
Table 6

Average number of strawberry mite (Phytonemus pallidus) per one strawberry leaf on different cultivars and genotypes in 2012

\begin{tabular}{|c|c|}
\hline Number of motile forms per 1 leaf & Cultivars and genotypes \\
\hline 0 & $\begin{array}{l}\text { 'Dukat', 'Filut', 'Flair', 'No. 03-08-01', 'Real', 'Salut', 'Vima Rina', } \\
\text { 'Maling Pearl' }\end{array}$ \\
\hline $0.1-2.0$ & $\begin{array}{l}\text { 'Algol', 'Camarosa', 'Dana', 'Darselect', 'Dominika', 'Eros', 'Florence', } \\
\text { 'Florin', 'Gerida', 'Gloria', 'Grandarosa', 'Kama', 'Kaster', 'Kent', } \\
\text { 'Marmolada' (Onebor), 'Polka', 'Senga Sengana', 'Syriusz' }\end{array}$ \\
\hline $2.1-4.0$ & 'Susy', 'Tenira', ‘DO 01501', 'Evie 2', 'Selva' \\
\hline $4.1-10.0$ & 'Elianny', 'Elkat', 'Pandora', \\
\hline $10.1-20.0$ & 'Alfa', 'Elsanta', 'Fara', 'Vega', 'Ventana', 'Vima Xima', 'DM 02752' \\
\hline$>20.1$ & 'Evita', 'Feriusz', 'Hokent', 'Honeoye', 'Karel', 'Albion', \\
\hline
\end{tabular}

Table 7

Average number of strawberry mite (Phytonemus pallidus) per one strawberry leaf on different cultivars and genotypes in 2013

\begin{tabular}{ll}
\hline Number of motile forms per 1 leaf & Cultivars and genotypes \\
\hline 0.0 & 'Dukat', 'Flair', 'Real', 'Salut', 'Vima Rina', 'Malling Pearl', 'Syriusz', \\
$0.1-2.0$ & 'Algol', 'Camarosa', 'Dana', 'Darselect', 'Dominika', 'Eros', 'Filon', \\
& 'Filut', 'Florence', 'Florin', 'Gerida', 'Gloria', 'Grandarosa', 'Kama', \\
& 'Kaster', 'Kent', 'Marmolada' (Onebor), 'Pandora', 'Polka', 'Senga \\
& Sengana', 'Susy', 'Tenira', 'DO 01501', 'Evie 2', 'Selva' \\
$2.1-4.0$ & 'Elianny', 'Alfa', \\
$4.1-10.0$ & 'Elkat', 'Elsanta', 'Fara', 'Vega', 'Ventana', 'Vima Xima', 'DM 02752', \\
$10.1-20.0$ & 'Feriusz', 'Karel', 'Honeoye', \\
$>20.1$ & 'Evita', 'Hokent', 'Albion' \\
\hline
\end{tabular}

Vertimec EC 018 used twice at a dose of 0.75 1/ha significantly decreased the population of strawberry mites throughout the entire observation period, up to 5 weeks after the second treatment. The number of mites was at a low level, below the threshold level. In most observation periods the efficacy of treatment was noted at the level 93.0-98.0\%. Vertimec $018 \mathrm{EC}$ at the rate 1.0 1/ha applied as a single treatment showed a high and immediate efficacy for up to 4 weeks after the treatment. Later an increase of mite population was noted.

In 2013 the best results in the control of strawberry mite was also obtained after one application of Vertimec 018 EC-1.0 1/ha (Tables 4 and 5). The number of motile forms and eggs was low for up to 5 weeks after treatment. The single application of the other product was less effective - low pest population was noted for three weeks after treatment and subsequently increased.

Generally, in the control of the strawberry mite abamectin as Vertimec 018 EC showed good efficacy, but the long-lasting effect was observed only after two applications of the product. These results confirm earlier observations $[8,10,11,19,20]$. Naturalis (Beauveria bassiana) + Protector proved to be more effective than the treatment of Naturalis+Terra Sorb ${ }^{\circledR}$ Complex, however the result of pest control was poorer and of short duration than after application of Vertimec 018 EC. In other experiments carried out in Poland good control of the strawberry mite was obtained after application of fenpiroxymate as Ortus 05 SC and pyridaben as Sanmite 50 WP [11], which are currently registered to control the pest. Also new active substance spirotetramat contained in the product Movento $100 \mathrm{SC}$ applied after fruit harvest showed to be highly effective in the control of the strawberry mite [19, 21].

\subsection{Susceptibility of cultivars}

Two years of observations proved that some strawberry cultivars such as: 'Dukat', 'Flair', 'Real', 'Salut', 'Vima Rina', 'Malling Pearl,' were not infested by the strawberry mite - no pest was observed on plants (Tables 6 and 7). 
The lowest number of the pest was noted on cultivars: 'Algol', 'Camarosa', 'Dana', 'Darselect', 'Dominika', 'Eros', 'Florence', 'Florin', 'Gerida', 'Gloria', 'Grandarosa', 'Kama', 'Kaster', 'Kent', 'Marmolada' (Onebor), 'Polka', 'Senga Sengana', 'Syriusz', 'Filut', 'No. 03-08-01'. While the highest population of mites was observed on 'Evita', 'Hokent', 'Albion', 'Feriusz', 'Honeoye' and 'Karel'.

It also needs to be stressed that the number of strawberry mite differs depending on the variety and genotype. This result is also in accordance with earlier studies' results [4-6].

\section{Conclusions}

Vertimec $018 \mathrm{EC}$ at the rate $1.0 \mathrm{l} / \mathrm{ha}$, applied as a single treatment, showed a high and immediate efficacy for up to 4 weeks after the application, later an increase of mite population was noted.

Vertimec EC 018 used twice at the rate 0.75 1/ha significantly decreased the strawberry mites population throughout the entire observation period for up to five weeks after the second treatment. The mite population was low, below the threshold level.

Product Naturalis at a dose of 1.0 1/ha+Protector at 0.3 1/ha applied twice after fruit harvest showed satisfactory results (over $80.0 \%$ efficacy), but only within one week after the second treatment.

Product Naturalis at a dose of 1.0 and 1.5 1/ha+Protector at 0.3 1/ha applied once in the spring, showed good control three weeks after treatment.

Naturalis $\left(1.0\right.$ 1/ha) + Terra Sorb ${ }^{\circledR}$ Complex (1.5 1/ha) applied once in the spring showed high efficacy $(79.0 \%)$, but only three weeks after treatment.

The strawberry mite population was different, depending on the cultivar.

The strawberry mite did not infect some cultivars such as 'Dukat', 'Flair', 'Real', 'Salut', 'Vima Rina', 'Malling Pearl'. The pest was not observed on experimental plots within two years of observations.

Very numerous population of the strawberry mite was noted on strawberry cultivars such as 'Evita', 'Hokent', 'Albion', 'Feriusz', 'Honeoye' and 'Karel'.

\section{Acknowledgments}

These studies were realized within the framework of the EUBerry project 'The sustainable improvement of European berry production, quality and nutritional value in a changing environment: Strawberries, Currants, Blackberries, Blueberries and Raspberries" (7th Framework Program) supported by the European Commission (Grant Agreement No. 265942).

\section{References}

[1] Ruszkowski J. Szkodniki sadów obserwowane w, Polsce w roku 1931 [Pests of orchards observed in Poland in 1931, in polish], Rocznik Ochrony Roślin (B), Warszawa 1935;2:81-96

[2] Alford DV. The effect of Tarsonemus fragariae Zimmermann (Acarina: Tarsonemidae) on strawberry yields. Ann App Biol. 1972;70:13-8.

[3] Alford DV. Pests of fruit crops A color Handbook. Manson publishing Ltd. 2007:419-20.

[4] Łabanowska BH. Harmfulness of the strawberry mite (Phytonemus pallidus ssp. fragariae Zimm.) and the two-spotted spider mite (Tetranychus urticae Koch.) on the strawberry and susceptibility of some cultivars for infestation. In: Materiały XXVI Sympozjum Akarologicznego, "Akarologia Polska u progu nowego tysiąclecia", SGGW, Warszawa, 2000;358-61.

[5] Łabanowska BH. Spread of the strawberry mite (Phytonemus palidus ssp, fragariae Zimm.) on thirteen strawberry cultivars. J Fruit Ornam Plant Res. 2004;12:105-11.

[6] Łabanowska BH. Susceptibillity of strawberry cultivars to infestation by the strawberry mite (Phytonemus palidus ssp, fragariae Zimm.). J Fruit Ornam Plant Res. 2006;14:189-97.

[7] Łabanowska BH. Pottential agents for controlling the strawberry mite (Phytonemus palidus ssp, fragariae Zimm.) after the withrawal of endosulfan. J Fruit Ornam Plant Res. 2006;14(3):67-72.

[8] Łabanowska BH. Effectiveness of the acaricides in the control of the strawberry mite - Phytonemus pallidus ssp. fragariae Zimm. Fruit Sci Rep. 1992;19(3):137-46. 
[9] Łabanowska BH. Zwalczanie roztocza truskawkowca (Phytonemus pallidus ssp. fragariae): nowymi akarycydami, [Control of strawberry mite (Phytonemus pallidus ssp. fragariae Zimm.) with new acaricides, in polish with English summary]. Prog Plant Prot/Post Ochr Roślin. 2003;43(2):781-83

[10] Łabanowska BH. Efficiency of new-generation acaricides in controlling the strawberry mite - Phytonemus palidus ssp, fragariae Zimm. on strawberry. Biological Lett. 2006;43(2):335-40.

[11] Łabanowska BH. Efficacy of Ortus 05 SC (fenpiroxymate) in the control of the strawberry mite (Phytonemus pallidus Banks) on strawberry plantations after fruit harvest, in polish with English summary. Prog Plant Protection/Post Ochr Roślin. 2014;54(1):44-50.

[12] Raudonis L. Effect of spirodiclofen on the strawberry mite, Tarsonemus pallidus (Acari: Tarsonemidae) in strawberries. Sodinninkysteirdarzininkyste Babtai. 2005;24(2):64-7.

[13] Raudonis L. Comparative toxicity of spirodiclofen and lambdacihalotrin to Tetranychus urticae, Tarsonemus pallidus and predatory mite Amblyseius andersoni in a strawberry site under field conditions. Agron Res. 2006;4:317-22.

[14] Raudonis L. The effect of abamectin on strawberry mite Tarsonemus pallidus (Acari: Tarsonemidae) in strawberries. Scientific works of the Lithuanian Institute of Horticulture and Lithuanian University of Agriculture. Sodininkysteir Darzininkyste. 2006;25(4):153-61.

[15] Easterbrook MA, Fitzgerald JD, Solomon MG. Biological control of strawberry tarsonemid mite Phytonemus pallidus and two-spotted spider mite Tetranychus urticae on strawberry in UK using species of Neoseiulus (Amblyseius) (Acari: Phytoseiidae). Exp Appl Acarol. 2001;25(1):25-36.

[16] Svensson B. Successful bio-control of the strawberry mite Phytonemus pallidus with the predatory mite Neoseiulus cucumeri in organic outdoor production of strawberries (Fragaria x ananassa Duch.) in Sweden. Acta Hort. 2008;842(2):657-60.

[17] Tuovinen T. Integrated control of strawberry mite (Phytonemus pallidus) in the Nordic multi-year growing system. Acta Hort. 2000;525: 389-92.

[18] Tuovinen T. Biological control of strawberry mite (Phytonemus pallidus) by using predatory mites in strawberry. Acta Hort. 2002;567: 675-78.

[19] Łabanowska BH, Korzeniowski M, Piotrowski W. New product for the control of strawberry mite (Phytonemus pallidus) on strawberry plantation in Poland after fruit harvest (in press).

[20] Fountain MT, Harris AL, Cross JV. The use of surfactants to enhance acaricide control of Phytonemus pallidus (Acari: Tarsonemidae) in strawberry. Crop Protection. 2010;29(11):1286-92.

[21] Łabanowska BH, Piotrowski W, Korzeniowski M, Gasparski T. Efficacy of spirotetramat (Movento 100 SC) in the control of strawberry mite (Phytonemus pallidus) on strawberry plantations in Poland. Future IPM in Europe. Riva del Garda, Italy, 19-21, 2013, Book and Abstract. 